\title{
Agroturystyka w rozwoju przestrzennym pogranicza Warmii i Mazur. Studium przypadku Świerkocina
}

\section{Agritourism in the spatial development of the borderland of Warmia and Mazury. Case study Świerkocin}

\section{Streszczenie}

Artykuł jest wynikiem badań możliwego wpływu agroturystyki na rozwój przestrzenny pogranicza Warmii i Mazur na podstawie studium przypadku wsi Świerkocin. Wykorzystano metodę analizy krytycznej oraz badania in situ dla zakresu wsi Świerkocin oraz regionu, mającego bezpośredni wpływ na omawianą miejscowość. Potencjał zaistnienia struktur agroturystycznych został omówiony na tym przykładzie ze względu na dogodną lokalizację oraz kierunki rozwoju proponowane przez władze powiatowe. Wieś posiada sprzyjające warunki dla rozwoju struktur agroturystycznych, związane z bardzo niską intensywnością zabudowy, charakterystycznym archetypem architektonicznym, rozwiniętą aktywnością turystyczną oraz lokalizacją w naturalnych obszarach Pojezierza Mazurskiego. Artykuł przedstawia potencjał rozwoju agroturystki w Świerkocinie na podstawie analiz znaczenia tej formy turystyki zarówno w całej Polsce, jak i w regionie pogranicza Warmii i Mazur.

Słowa kluczowe: agroturystyka, Warmia i Mazury, kontekstualizm, turystyka 


\begin{abstract}
The article is a result of a research on a possible impact of agritourism on the spatial development of the borderland of Warmia and Mazury, based on the case study of the village Świerkocin. Text was built with the method of critical analysis and in situ research for the scope of the village Świerkocin and the region that have a direct impact on the discussed place. The potential for the emergence of agritourism structures has been discussed on this example due to the convenient location and development directions proposed by the poviat authorities. The village has favorable conditions for the development of agritourism structures related to a very low intensity of buildings, a characteristic architectural archetype, developed touristic layer and location in the natural areas of the Masurian Lake District. The article describes potential of agritourism development in Świerkocin. It is based on the analysis of significance of this touristic form, both in Poland and in the border region of Warmia and Mazury.
\end{abstract}

Keywords: agritourism, Warmia and Mazury, contextualism, tourism 


\section{WSTĘP}

Artykuł powstał jako rezultat badań prowadzonych z wykorzystaniem metody analizy krytycznej oraz badań in situ i dotyczy wpływu agroturystyki na rozwój przestrzenny na pograniczu Warmii i Mazur. Celem analiz było określenie potencjału turystycznego Świerkocina jako studium przypadku reprezentującego pogranicze kultur wspomnianych regionów. Zakres badania obejmuje wieś Świerkocin, zlokalizowaną na terenie Mazur, ale w obszarze bezpośrednio graniczącym z Warmią. Miejscowość charakteryzuje bardzo niska intensywność zabudowy oraz duża zasobność terenów siedliskowych. Inspiracją do podjęcia tematu były warsztaty terenowe oraz eksploracja okolic wsi Świerkocin. Badania były prowadzone na przełomie września i października 2020 roku. Ich rezultaty zostały wykorzystane w analizach dokonanych w czerwcu 2021 roku.

W ostatnim czasie można zaobserwować zmieniające się potrzeby społeczeństw, w których mieszkańcy miast poszukują odpoczynku od atmosfery dynamicznych aglomeracji oraz możliwości czasowego zerwania z właściwym im intensywnym tempem życia. W Polsce kierunek ten przybiera na sile wraz z postępującym bogaceniem się społeczeństwa oraz ogólnoświatowymi zmianami związanymi z postępem technologicznym i procesami globalizacyjnymi. Obserwujemy zmianę preferencji kulturowych, modelu oraz stylu życia. Kształtują one potrzebę poszukiwania innych, alternatywnych form spędzania wolnego czasu, w tym realizacji potrzeb wypoczynkowych (Dorocki, Szymańska, Zdon-Korzeniowska, 2013: 38-58). W związku z tym popularnym wyborem mogą być struktury rozwijającej się turystyki rolniczej, które oferują możliwość relaksu wśród naturalnej zieleni oraz w spokojnej, sielskiej atmosferze wsi ${ }^{1}$. Tekst ma określić cechy miejscowości, w której może rozwijać się taka forma wypoczynku, oraz wskazać wymagania, jakie powinna ona spełniać. W tym celu wykorzystane jest studium przypadku Świerkocina.

\section{AGROTURYSTYKA}

\subsection{DEFINICJA}

Słowo „agroturystyka” składa się z dwóch składowych: „turystyka” jest zorganizowanym wyjazdem poza miejsce stałego zamieszkania; „agro-" jest pierwszym członem wyrazów złożonych, wskazującym na ich związek z rolą lub rolnictwem². Agroturystyka jest zatem formą rekreacyjną realizowaną na terenie wsi, często związaną z charakterem rolniczym gospodarstwa. Ostatnio popularne staje się łączenie kultywowanego profilu

\footnotetext{
http://agroturystykapolska.pl/artykuly/wakacje-na-wsi-1/moda-na-agroturystyke-4 (dostęp: 20.02.2021)

2 https://sjp.pwn.pl/ (dostęp: 27.06.2021).
} 
rolniczego z działalnością dodatkową, usługami rekreacyjnymi i edukacyjnymi, które oferują turystom albo letnikom poszerzone możliwości spędzenia czasu „pod gruszą”, jak wciąż tradycyjnie nazywa się wczasy tego rodzaju.

Mikołaj Jalinik zdefiniował agroturystykę jako mikroprzedsiębiorstwa produkcyjno-usługowe zajmujące się prowadzeniem działalności gospodarczej, która polega na wytworzeniu jak najlepszego produktu turystycznego, będącego formą wypoczynku na terenie gospodarstwa (Jalinik, 2009: 119-137). Janusz Majewski zaś określa ją jako strukturę związaną wyłącznie z funkcjonującym gospodarstwem rolnym, gdzie produkcja roślinna i zwierzęca stanowią jedną z największych atrakcji dla turystów (Majewski, 2000).

\subsection{HISTORYCZNE ZNACZENIE AGROTURYSTYKI}

Istotne dla rozwoju agroturyzmu (jak początkowo nazywano tę formę wypoczynku) były rekomendacje XIX-wiecznych lekarzy, którzy zachęcali do spędzania czasu wśród wiejskiej przyrody. Była to reakcja na wiele złych nawyków pojawiających się wśród elity mieszczańskiej, żyjącej w coraz bardziej uprzemysłowionym mieście (Wiśniewski, 2006: 14-18). W następstwie rewolucji przemysłowej, a także procesów urbanistycznych powodujących narastanie liczby mas pracujących w miastach, pojawiła się potrzeba wiejskiej formy wypoczynku (Wojciechowska, 2006: 99-119). W Polsce, dzięki inicjatywie Spółdzielni Turystyczno-Wypoczynkowej „Gromada”, nastąpił znaczny rozwój letnisk oraz popularne stały się „wczasy pod gruszą", propagowane w ramach aktywizacji obsługi turystycznej na wsi. W drugiej połowie XX wieku nastąpił jednak regres w tej dziedzinie (Gurgul, 2005) - olbrzymie wymagania podatkowe zahamowały rozwój formy „pod gruszą”, a stan wojenny całkowicie ją pogrążył. Ożywienie nastąpiło dopiero w późnych latach 80. i 90. XX wieku, gdy agroturystyka stała się motorem aktywizacji gospodarczej obszarów wiejskich (Sikora, 2012). Po likwidacji monopolu państwowego indywidualni rolnicy mogli rozpocząć działalność w tym obszarze, co w efekcie spopularyzowało samą ideę. Rezultatem tego była kreatywna personalizacja oferty pod konkretne grupy odbiorców i unowocześnianie formy wczasów znanych z ubiegłego wieku (Kapusta, 2008). Zmianie uległ także wachlarz usług turystycznych oferowanych przez gospodarstwa rolne, pojawiła się kategoryzacja pakietów dla różnych form odbiorców, proponowano np. czynne uczestnictwo w życiu gospodarstwa, dla edukacji czy terapii (Dębniewska, Zaworska, 1998: 115).

\subsection{UWARUNKOWANIA ROZWOJU AGROTURYSTYKI W POLSCE}

Agroturystyka kształtuje się na zasadach rynkowych w miejscach, które cechują się wysokimi walorami krajobrazowymi. Tereny Polski są podatne na rozwój rolniczej turystyki, zwłaszcza na obszarach o niewielkim stopniu zurbanizowania oraz uprzemysłowienia. Najważniejszymi czynnikami rozwojowymi, korzystnymi dla prowadzenia gospodarstwa rolnego 
z funkcją agroturystyczną, są zasoby przyrodniczo-krajobrazowe, stosowne otoczenie prawne i organizacyjne (status rolnika) oraz pozyskiwanie wsparcia finansowego (Dębniewska, Zaworska, 1998: 115). Efektem lokalizacji gospodarstwa na terenie o sprzyjających walorach krajobrazowych może być zwiększenie się jego całościowego dochodu dzięki usługom turystycznym. Rozwój takich usług będzie miał wpływ na przyspieszenie rozwoju regionu.

Przepisy prawne traktują agroturystykę jako świadczenie usług turystycznych w gospodarstwie rolnym. Definiowana jest ona jako turystyka na terenach wiejskich, forma rekreacji w rejonie niezurbanizowanym, bezpośrednio związana z rolnictwem, gdzie poza produktem turystycznym oferuje się możliwość poznania specyfiki zawodu rolnika (Drzewiecki, 2002). Obecny model organizacyjny agroturystyki w Polsce ma postać czteroszczeblowej struktury, składającej się z:

1) gospodarstwa agroturystycznego,

2) ośrodków doradztwa rolniczego oraz regionalnych stowarzyszeń agroturystycznych,

3) Polskiej Organizacji Turystycznej,

4) właściwych ministerstw oraz organizacji międzynarodowych (Dziechciarz, 2007).

Mnogość aspektów funkcjonalnych w gospodarstwie agroturystycznym sprawia, że jest ono objęte nie tylko polityką rozwoju rolnictwa, ale także planami rozwoju obszarów turystycznych, ochrony środowiska, rozwoju małych i dużych przedsiębiorstw oraz politykami regionalnymi. Daje to możliwości pozyskiwania dodatkowych funduszy z dostępnych środków wsparcia w sektorze pozarolniczym. W planowaniu regionu ważne jest utworzenie zrównoważonego planu rozwoju przestrzennego, który uwzględniałby zachowanie kameralnego charakteru wsi, umożliwiającego odbiór jej atmosfery jako spokojnej, oraz proekologiczne myślenie. Agroturystyka pozwala na aktywizację obszarów wiejskich, poszerzanie zakresu działalności gospodarstw oraz tworzenie nowych miejsc pracy. Wpływa to na lokalną gastronomię, handel oraz przetwórstwo. Obecne tempo życia sprawia, że liczba turystów preferujących ten rodzaj wypoczynku się zwiększa, co powoduje, że aktywność agroturystyczna staje się ważną gałęzią regionalnej przedsiębiorczości (Surdacka, 2017: 1778-1783).

W Polsce agroturystyka cechuje się przywiązaniem do tradycji lokalnych, co wydaje się często zanikać w krajach Europy Zachodniej w związku z intensyfikacją i umasowieniem produkcji rolniczej, co oddziałuje na rodzime kultury. Rozwijanie różnych rodzajów działalności na terenie polskich wsi pozwala na tworzenie nowych miejsc pracy w sektorze pozarolniczym, jednak bezpośrednio związanych z gospodarstwem rolnym i jego tradycyjnym charakterem (Marks-Bielska, Babuchowska, 2013: 141-150).

Oferta pojedynczego gospodarstwa agroturystycznego jest przy tym jedynie składową produktu turystycznego na danym obszarze. Dla rozwoju całego sektora takich usług konieczna jest współpraca wielu podmiotów, zwłaszcza wsparcie samorządów terytorialnych. Sam produkt zależy od rozwoju gospodarki sieciowej lub klastrów turystycznych. Niezbędny jest współudział różnych podmiotów oraz kształtowanie partnerstwa publiczno-prywatnego (Dorocki, Szymańska, Zdon-Korzeniowska, 2013: 38-58) (il. 1). 


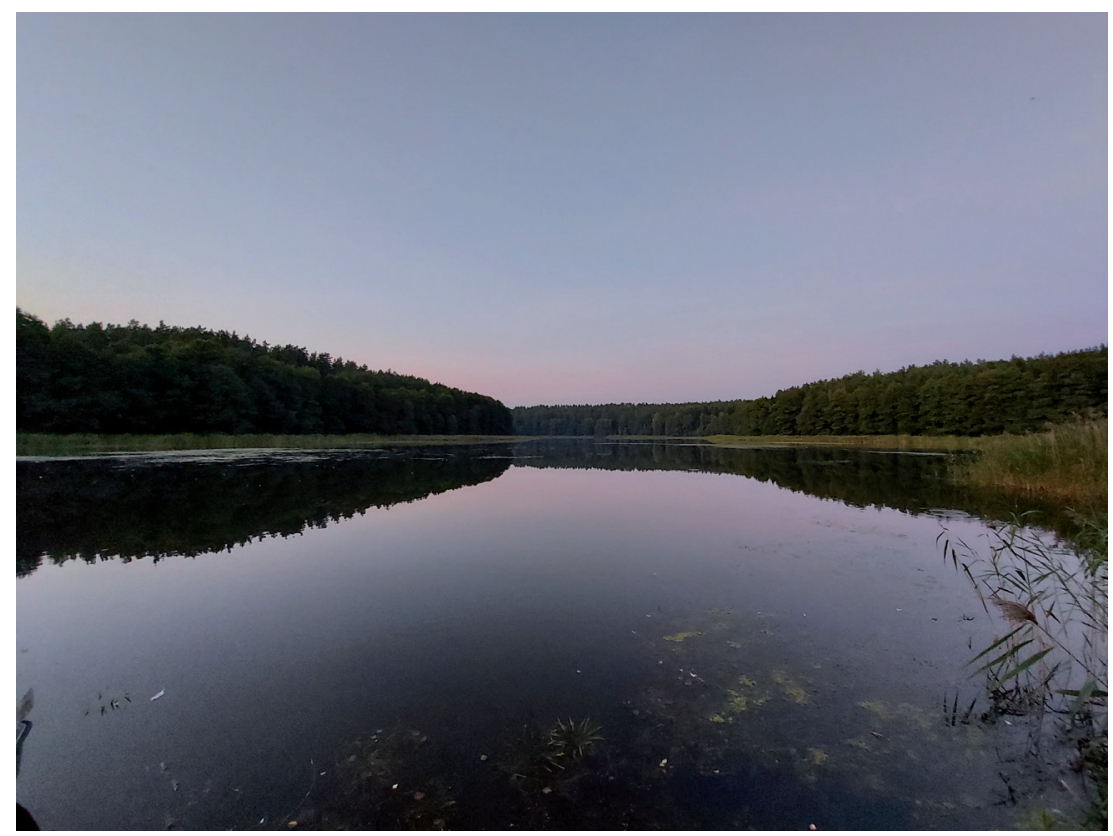

II. 1. Jezioro Czarne wieczorem. Fot. autor

\section{AGROTURYSTYKA POGRANICZA WARMII I MAZUR}

\subsection{CHARAKTERYSTYKA WARMII I MAZUR}

Województwo warmińsko-mazurskie położone jest w północno-wschodniej części Polski nad Zalewem Wiślanym. Dzięki zachowaniu dużych obszarów leśnych, czystych kompleksów jezior oraz licznych zabytków Warmia i Mazury są uznawane za jeden z najbardziej atrakcyjnych kierunków turystycznych w Polsce. Rejon ten znany jest jako „Zielone Płuca Polski”, co podkreśla jego naturalną, ekologiczną, prozdrowotną wartość. Po terenach Pomorza oraz terenach górskich mazurskie jeziora są trzecim celem wyjazdów wypoczynkowych w Polsce. Gminy wiejskie na terenach szczególnie atrakcyjnych turystycznie wykorzystują ich walory do rozwijania lokalnych form przedsiębiorczości. Wstąpienie Polski do Unii Europejskiej dało szansę pozyskania dodatkowych finansów na rozwój pozarolniczych obszarów wiejskich (Czaplicka-Kozłowska, 2009: 56-61). Teren województwa warmińsko-mazurskiego, w porównaniu do innych województw, charakteryzuje się bardzo małym zanieczyszczeniem atmosfery i wód oraz niskim stopniem degradacji powierzchniowej. Głównymi kompleksami leśnymi są puszcze Borecka, Piska, Nidzicka oraz Romincka. Na tym obszarze znajdują się także liczne jeziora, w tym dwa największe w Polsce Śniardwy i Mamry. Prawie połowa powierzchni całego województwa składa się z obszarów 
chronionych. W 2013 roku wyodrębniono tutaj 111 rezerwatów oraz około 2500 pomników przyrody ${ }^{3}$. Województwo warmińsko-mazurskie posiada największą średnią powierzchnię użytków rolnych w Polsce (porównywalną tylko z województwem zachodniopomorskim), oscylującą pomiędzy 23,7-28,7\% całości terenu. Zachowana naturalna tkanka krajobrazowa i kulturowa, w połączeniu z kameralnym charakterem gospodarstw rolniczych tego regionu, może korzystnie wpłynąć na jakość życia jego mieszkańców oraz na wartość produktu turystycznego, który oferują ${ }^{4}$. Dodatkowo region wyróżnia się stosunkowo wysokim wskaźnikiem ilościowym na tle państwa w obszarze gospodarstw rolniczych z działalnością inną niż rolnicza - jest ich 3,5-4,7\% spośród wszystkich. W tej grupie najliczniejszą „inną działalnością" jest właśnie agroturystyka, stanowiąca 32,1\%. Najlepszymi warunkami do rozwoju agroturystyki cieszą się powiaty giżycki, mrągowski, olsztyński, piski i szczeciński. Według przedstawicieli starostw powiatowych oraz lokalnych grup działania powiaty te cechują się największą jakością środowiska przyrodniczego oraz dysponują dużymi zasobami kulturowymi. W 2011 roku województwo warmińsko-mazurskie znajdowało się na trzecim miejscu pod względem liczby obiektów agroturystycznych (743 obiekty), zaraz za Podkarpaciem (989 obiektów) i Małopolską (1344 obiektów). Eksperci wojewódzcy jednocześnie podkreślali, że nie można opierać strategii rozwoju Warmii i Mazur jedynie na turystyce. Jest ona znaczącym, a w niektórych przypadkach głównym elementem dochodu, ale nie jest w stanie pokryć zapotrzebowania na nowe miejsca pracy w rejonie (Diagnoza wybranych aspektów..., 2015). Dokładnie określony potencjał agroturystyczny będzie omówiony na podstawie studium przypadku wsi Świerkocin, uwzględniającego jej lokalizację na pograniczu Warmii i Mazur oraz jej elementy charakterystyczne, czyli: bardzo niską intensywność zabudowy, bogatą tkankę lasów i jezior w granicach wsi, turystyczne ukierunkowanie miejscowości oraz stosunkowo dużą liczbę działek siedliskowych.

\subsection{CHARAKTERYSTYKA REGIONU}

Studium przypadku obejmuje teren wsi Świerkocin, jednak nie należy zapominać o wpływie sąsiadujących miejscowości. Teren gminy Olsztynek, poza wyraźnym centrum miejskim, cechuje się charakterem zabudowy zbliżonym do kształtu okolicznych wsi. Marózek, Swaderki, Pluski czy Mierki, sąsiadujące ze Świerkocinem, są wsiami małych rozmiarów, otoczonymi tkanką naturalną. Właśnie ograniczony rozwój miejscowości i niewielki stopień ingerencji w przyrodę powodują występowanie warunków atrakcyjnych dla turystów. Województwo warmińsko-mazurskie charakteryzuje się jednym z najniższych wskaźników gęstości zaludnienia, który wynosi 59 os. $/ \mathrm{km}^{2}$ (średnia w Polsce wynosi 122 os. $/ \mathrm{km}^{2}$ ). Dane z 2015 roku, dotyczące gminy Olsztynek, mówią o wskaźniku dla tych terenów - 37,3os./km²

3 http://encyklopedia.warmia.mazury.pl/index.php/Wojew\%C3\%B3dztwo_warmi\%C5\%84sko-mazurskie (dostęp: 03.04.2021).

4 https://invest.warmia.mazury.pl/pl/dlaczego-warmia-i-mazury/nasze-przewagi.html (dostęp: 28.04.2021). 
(Marks-Bielska, Babuchowska, 2013: 141-150). Od 2012 roku liczba miejsc oferujących noclegi w powiecie olsztyńskim wzrosła z 159 do 199 w 2019 roku5. W obrębie charakteryzowanej lokalizacji istnieje wiele obiektów agroturystycznych, z których największym zainteresowaniem cieszą się pensjonat „Natura” w Swaderkach, gospodarstwo „W Krainie Jezior i Lasów” w Marózku oraz „Kolonia Mazurska” w Mierkach. Działają one całorocznie, jednak wyraźny wzrost zainteresowania pojawia się w miesiącach czerwiec-wrzesień oraz styczeń-luty. Pensjonat w Swaderkach opiera swoją działalność na walorach krajobrazowych oraz umożliwiających aktywizowanie wypoczynku, zwłaszcza dzięki rzece, która przebiega przez teren gospodarstwa. Pozwala to na ukierunkowanie oferty, która obejmuje spływy kajakowe oraz kąpiele. Na terenie obiektu swobodnie poruszają się niewielkie zwierzęta gospodarcze ${ }^{6}$. Ośrodek „W Krainie Jezior i Lasów” kierunkuje swój profil w stronę połowu ryb, poza zapewnieniem walorów krajobrazowych7. „Kolonia Mazurska” z kolei swoją działalność koncentruje na aktywnym spędzaniu czasu wśród zwierząt, a największą atrakcję stanowią konie ${ }^{8}$. Oprócz tego najpopularniejszymi aktywnościami w istniejących gospodarstwach agroturystycznych są grille, ogniska, zbieranie owoców lub grzybów oraz wycieczki po szlakach tematycznych (Marks-Bielska, Babuchowska, 2013: 141-150).

\subsection{CHARAKTERYSTYKA WSI ŚWIERKOCIN}

Ponieważ agroturystyka jest rozwijającym się obecnie kierunkiem, nie tylko wsie o dominującej roli turystyki wśród „innej działalności” rozszerzają w tym zakresie swoją ofertę. Popularyzacja „wczasów pod gruszą” zaczyna obejmować miejscowości mniej znane, które zachwycają kameralnością i autentycznością. Składa się na to tkanka walorów przyrodniczych, warunków ekonomicznych, rolniczego skategoryzowania gospodarstwa, tradycji oraz kontekstualizmu w otaczającym krajobrazie, także jego okolic i powiązań. Istotne są też elementy kultury lokalnej oraz formy integracji ze społecznością obszarów wiejskich ${ }^{9}$ (il. 2).

Świerkocin to mała polska wieś o strukturze w formie ulicówki, położona w województwie warmińsko-mazurskim, w powiecie olsztyńskim, w gminie Olsztynek. Miejscowość ta nie jest duża - liczba ludności w 2011 roku wynosiła 69 osób. Wskaźnik gęstości zaludnienia był na poziomie $12 \mathrm{os} . / \mathrm{km}^{210}$. Między innymi dzięki temu zachowana jest tu naturalna tkanka lasów, jezior, rzek i łąk. Główne skupisko budynków, centrum wsi, to w większości poniemieckie obiekty leżące przy Jeziorze Wysokim. Tam też znajduje się kilka ośrodków

\footnotetext{
5 https://bdl.stat.gov.pl (dostęp: 27.06.2021).

6 http://natura-group.com.pl (dostęp: 27.06.2021).

7 http://agroturystyka-zakrzewscy.pl/ (dostęp: 27.06.2021).

8 https://koloniamazurska.pl/ (dostęp: 27.06.2021).

9 http://agroturystykapolska.pl/artykuly/wakacje-na-wsi-1/moda-na-agroturystyke-4 (dostęp: 20.02.2021).

10 http://encyklopedia.warmia.mazury.pl/index.php/\%C5\%9Awierkocin (dostęp: 31.06.2021).
} 


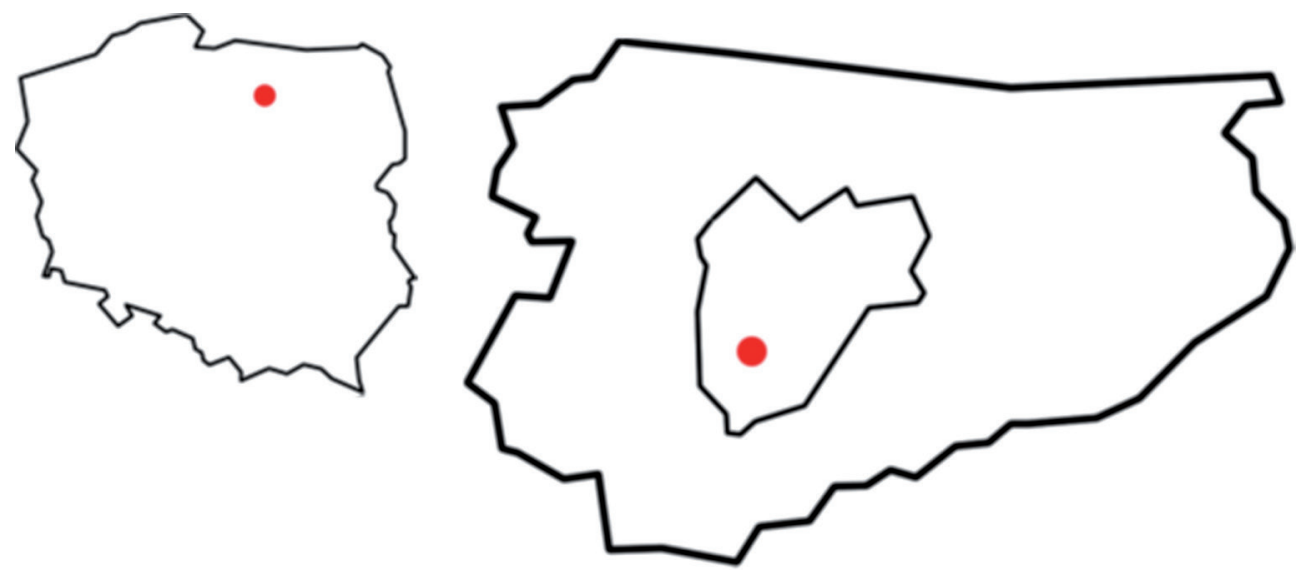

II. 2. Położenie Świerkocina w Polsce oraz w województwie warmińsko-mazurskim. Fot. autor

wypoczynkowych, zwykle o charakterze domków na wynajem, z widokiem na naturalny krajobraz. Pozostała część wsi to przede wszystkim lasy sosnowe oraz łąki otaczające jeziora. Naturalnej florze towarzyszy bogata fauna, pozwalająca zaobserwować wiele gatunków niespotykanych nigdzie indziej, w tym takich, które są zagrożone wyginięciem. W stosunku do innych osad Świerkocin jest odizolowany. Najbliższym większym ośrodkiem miejskim jest Olsztynek, siedziba gminy (Kuźniewski, 2007).

\subsection{POWIAZZANIA KOMUNIKACYJNE ŚWIERKOCINA}

Świerkocin znajduje się w przestrzeni otoczonej tkanką naturalną. Wieś jednak posiada dogodne połączenia komunikacyjne. Połączona jest z drogą krajową nr 58. Trasa ta łączy Olsztynek ze Szczuczynem. Po zjechaniu z drogi krajowej w stronę Świerkocina, do jego centrum kierujemy się meandrującą utwardzoną jezdnią. Wieś jest usadowiona historycznie wzdłuż tej osi drogi. Tę zasadę przełamuje nowa zabudowa, która jest zlokalizowana w obszarach graniczących bezpośrednio z lasami, będąca przede wszystkim zabudową turystyczną i rekreacyjną. Miasto Olsztynek posiada połączenie kolejowe oraz obsługujący je dworzec. Drugi przystanek kolejowy znajduje się na północ od Olsztynka i służy obsłudze lądowiska Gryźliny. Dogodne połączenie z Olsztynkiem zapewnia także droga ekspresowa S51, łącząca Olsztynek z Olsztynem. S51 łączy się z drogą ekspresową S7 w południowo-zachodniej części gminy Olsztynek ${ }^{11}$ (il. 3).

11 https://www.gddkia.gov.pl/pl/ (dostęp: 27.06.2021). 
Analiza komunikacji wsi

Świerkocin

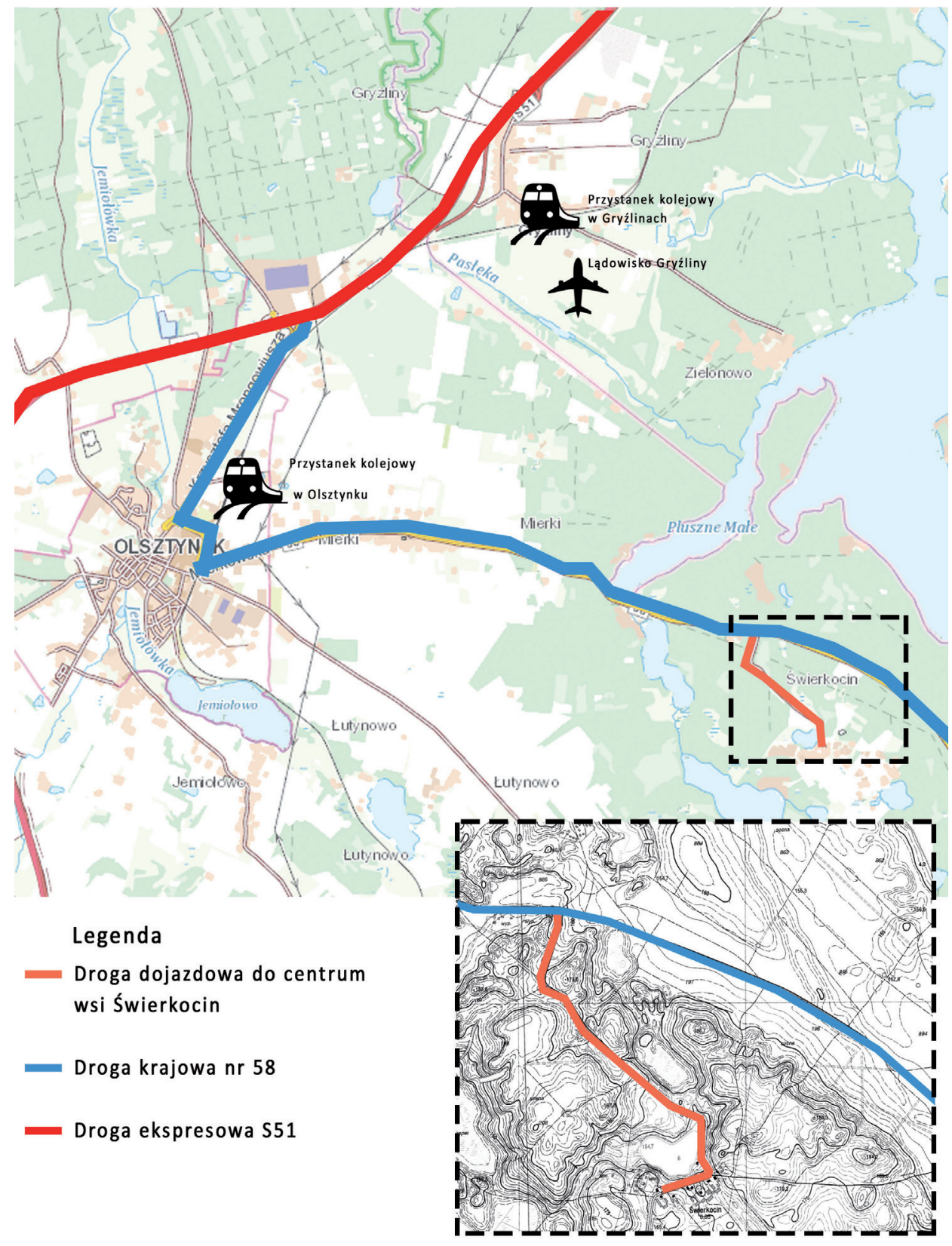

II. 3. Powiązanie komunikacyjne Świerkocina z Olsztynkiem. Oprac. własne 


\subsection{ZASOBY MIEJSCOWOŚCI}

Dla rozwoju miejscowości w zakresie turystyki ważne jest, jakie usługi jest ona w stanie zaoferować. Gospodarstwo agroturystyczne to: miejsce (kierunek wyjazdu), usługa (pakiet operatora turystycznego) oraz pewne dobra materialne. Wszystkie te aspekty mogą definiować sukces produktu turystycznego, lecz w przypadku agroturystyki produkt ten jest bardziej złożony. Ważną częścią jest otoczenie oraz zróżnicowany klimat miejsca, który ma zapewnić spokój i ciszę, ale także zachęcić turystę do wniknięcia w obcy dla niego świat. To, co buduje klimat miejsca, to jego odrębność od innych, uwarunkowana historią, społecznością zamieszkującą dany obszar, a także walorami przyrodniczymi oraz kulturowymi (Marciszewska, 2010: 13-21).

\subsubsection{ZASOBY DZIEDZICTWA KULTUROWEGO}

\subsubsection{RYS HISTORYCZNY}

Świerkocin, jak wiele innych wsi zgrupowanych wokół większego organizmu o miejskim charakterze, którym w tym przypadku jest Olsztynek, dzieli burzliwą historię całego tego obszaru. Pierwsze wzmianki o Świerkocinie i Olsztynku datowane są na XIV wiek, po tym jak okoliczne ziemie zostały przejęte przez zakon krzyżacki oraz objęte akcją kolonizacyjną. Kraina ta była pokryta puszczami. Tylko w niektórych miejscach ich ciągłość była przerywana, dając miejsce na niewielkie osady pruskie. O Świerkocinie wiadomo, że ucierpiał podczas wojen polsko-krzyżackich w 1410 roku, a później dzielił losy Olsztynka związanego z Prusami Książęcymi. Mimo zmian władz przez 100 lat szczęśliwym trafem wojny omijały Olsztynek, pozwalając mu na rozwój. Utworzono starostwo, Olsztynek stał się centrum kościelnym, naprawiono mury, a w mieście działał szpital. Głównym źródłem utrzymania mieszkańców były rzemiosło, handel oraz - w mniejszym stopniu - rolnictwo. Wiek XVII przyniósł koniec złotej ery dobrobytu, gdy wojny, pożary, głód oraz epidemie nawiedziły tę krainę. Najpierw na terenie Prus Książęcych zniszczeń dokonywali Szwedzi, a później miasto spalili Tatarzy (walki związane ze zdradą Fryderyka Wilhelma III), czego następstwem było pojawienie się nie tylko głodu po spaleniu wielu ważnych obiektów i wymordowaniu mieszkańców, ale także epidemii dżumy. W 1685 roku wybuchł z kolei pożar, który pochłonął kościół, plebanię, ratusz i wiele domów mieszczańskich. Miasto wskutek katastrofy i znacznego zubożenia ludności oraz tkanki miejskiej zostało zwolnione z podatków w celu odbudowy struktury miejskiej (Toeppen, 2004) (il. 4). Wtedy było już częścią państwa brandenbursko-pruskiego, później Prus Wielkich, i nosiło nazwę pruską Amellingi lub niemiecką Hohenstein, a wieś Świerkocin nazywała się Schwirgstein.

Po pożarze Olsztynka podjęto zatem próby odbudowy dawnej świetności miasta. Jednakże w 1708 roku wybuchła kolejna epidemia dżumy, która powtórnie przetrzebiła ludność miasta. Kolejny pożar w 1804 roku strawił niemal wszystko. Od 1871 roku miasto znajdowało się w granicach cesarskich Niemiec. W czasie I wojny światowej zostało zajęte przez wojska 


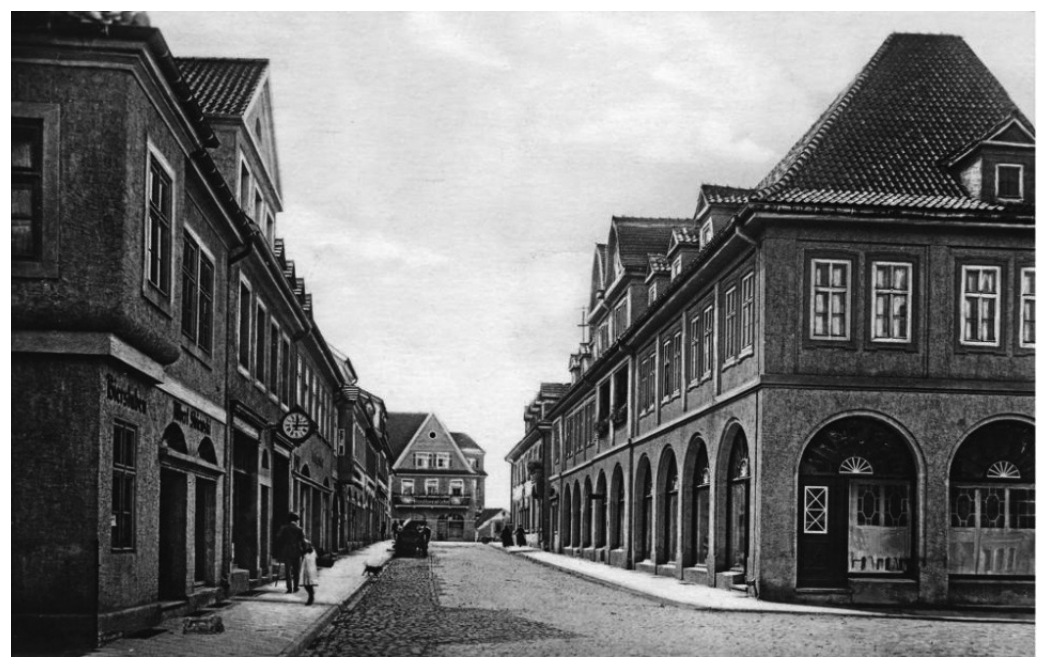

II. 4. Zdjęcie sprzed II wojny światowej. Autor nieznany (https://olsztynek.pl/miasto-i-gminaolsztynek/zdjecia-sprzed-ii-wojny-swiatowej/)

rosyjskie, a w trakcie potyczek uszkodzono znacznie zabudowę i infrastrukturę miejską (bitwa pod Tannenbergiem w 1914 roku). W 1945 roku Olsztynek został zniszczony przez wojska sowieckie (mocno ucierpiał też monument tannenberski). Ostatecznie, wraz ze Świerkocinem, znalazł się w granicach Polski (Kuźniewski, 2007).

\subsubsection{ZABYTKI}

Sam Świerkocin nie posiada zabytków. Najbliższym ośrodkiem o znacznych zasobach kulturowych jest Olsztynek. Mimo historii sięgającej XIV wieku architektura jest tu stosunkowo nowa, postmodernistyczna, co wynika z dziejów miasta, które było kilkukrotnie niszczone i odbudowywane. Świadczy o tym choćby to, jak wyglądają płyta rynku oraz otaczające ją budynki, architektura Miejskiego Domu Kultury, pierzei zabudowy, kościołów oraz budynków przemysłowych. Na miejscu spalonego w 1685 roku ratusza nowy powstał dopiero w 1714 roku i mimo znacznych zniszczeń miasta w 1945 roku szczęśliwie ocalał, choć odbudowana struktura budynków na rynku całkowicie do niego nie pasuje. Natomiast nadal jest widoczny praktycznie cały zarys murów miasta, będąc jednym z niewielu zachowanych i tak starych zabytków w tym regionie ${ }^{12}$. Zachowanym zabytkiem, datowanym na XIV wiek, jest średniowieczny zamek wzniesiony na polecenie komtura ostródzkiego. Zbudowany jest na planie czworoboku, z czego trzy jego boki były murowanymi budynkami, a czwarty pełnił funkcję muru oraz bramy wjazdowej (Darmochwał, Rumiński, 1996) (il. 5).

12 https://olsztynek.pl/turystyka/zabytki/ (dostęp: 20.11.2020). 


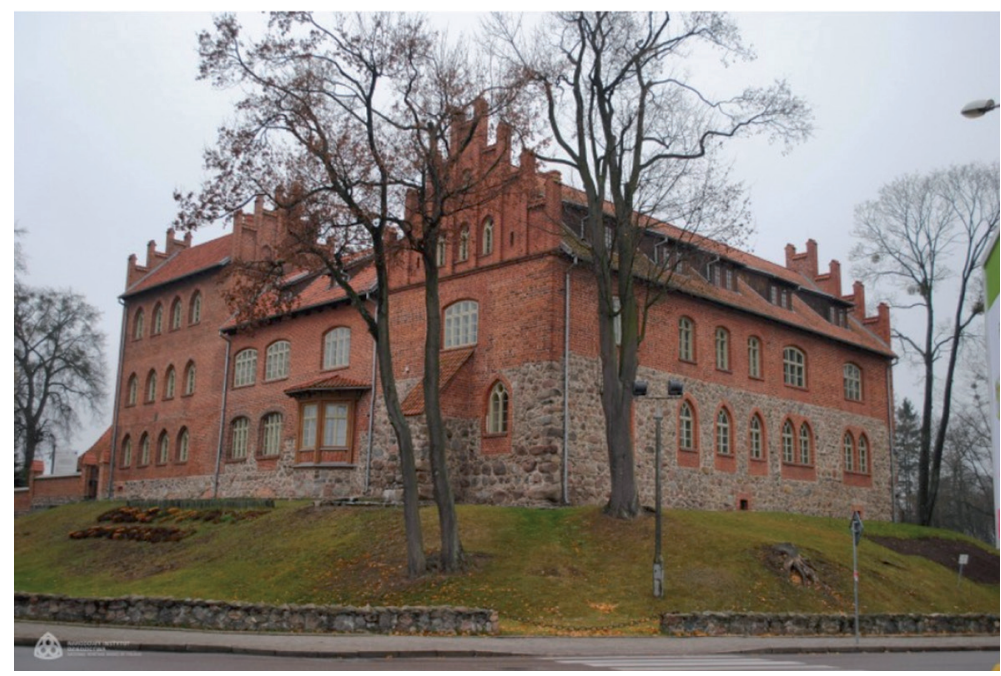

II. 5. Zamek w Olsztynku, widok ogólny z 2014 r. Fot. A. Mackiewicz (https://zabytek.pl/pl/obiekty/olsztynek-zamek-krzyzacki-ob-szkola/)

\subsubsection{MUZEA, PARKI I GALERIE}

Na terenie Olsztynka znajduje się Muzeum Budownictwa Ludowego - Park Etnograficzny w Olsztynku. Jest to jeden z najstarszych skansenów tego typu w Polsce, a jego początek sięga 1909 roku. Na miejscu można zobaczyć przede wszystkim budynki stworzone z drewna, kamienia i cegły, przykryte trzciną albo paloną dachówką ceramiczną ${ }^{13}$.

Na poddaszu ratusza w Olsztynku ulokowano Multimedialne Muzeum Obozu Jenieckiego Stalag IB i Historii Olsztynka, gdzie można dowiedzieć się więcej na temat całej gminy za pomocą nowoczesnych form przekazu ${ }^{14}$.

\subsubsection{ZASOBY PRZYRODNICZE I KRAJOBRAZOWE}

\subsubsection{CHARAKTERYSTYKA TKANKI KRAJOBRAZOWEJ}

Lasy zajmują ponad 52\% powierzchni gminy. Skupiska drzew występują w stosunkowo zwartych kompleksach, przede wszystkim jako bory świeże i mieszane z przewagą sosny (ok. 80\% składu drzewostanów), przy czym większość z nich objęta jest już statusem ochrony. Wśród występujących tam zwierząt główną i najbardziej zróżnicowaną grupą są ptaki. Na terenie lasów występuje także zwierzyna łowna, np. sarny, jelenie, dziki i inne (il. 6) ${ }^{15}$.

\footnotetext{
13 https://muzeumolsztynek.pl/ (dostęp: 16.04.2021).

14 https://olsztynek.pl/turystyka/atrakcje-turystyczne/ (dostęp: 14.12.2020).

15 https://olsztynek.pl/miasto-i-gmina-olsztynek/przyroda/ (dostęp: 13.12.2020).
} 


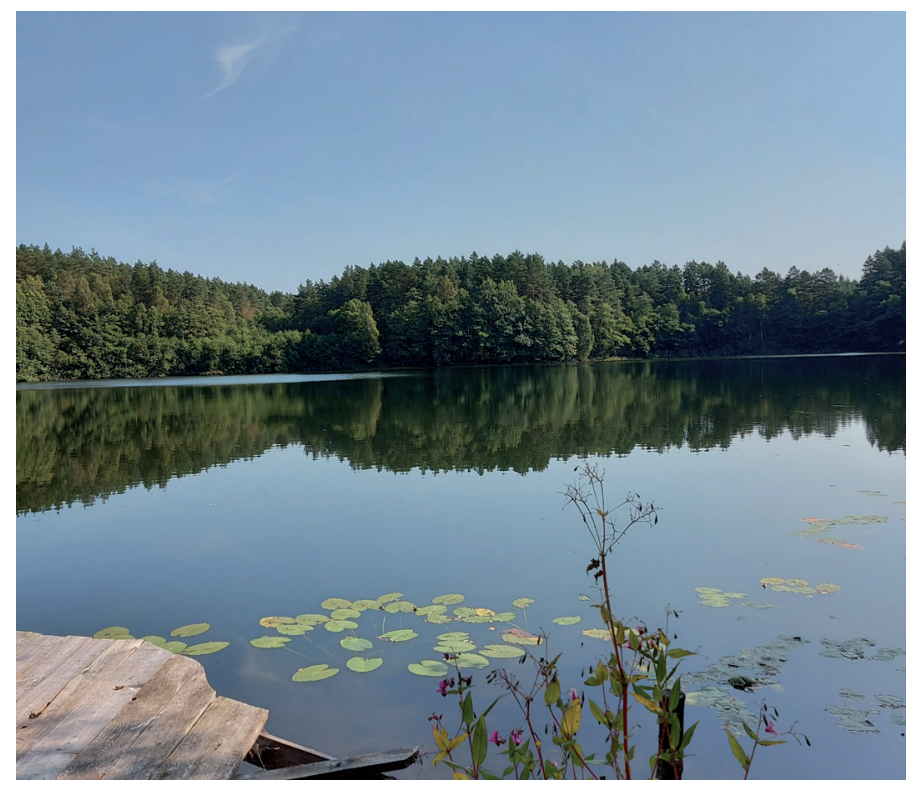

II. 6. Widok na Jezioro Czarne z działki na południu Świerkocina. Fot. autor

\subsubsection{SZLAKI I REZERWATY}

Dzięki występowaniu nienaruszonej tkanki leśnej, która jest schronieniem dla wielu gatunków zwierząt, ponad 70\% obszaru zostało objęte ekologicznym systemem obszarów chronionych. W okolicach gminy znajdują się liczne rezerwaty przyrody ${ }^{16}$.

Jednym z najważniejszych szlaków turystycznych pogranicza Warmii i Mazur jest Szlak Kopernikowski. Związany jest on z działalnością naukową Mikołaja Kopernika. W samym województwie warmińsko-mazurskim odcinek tego szlaku liczy 232 kilometry i wiedzie przez kilka większych ośrodków, w tym przez Olsztynek, gdzie można pozyskać informacje o związkach Mikołaja Kopernika z tym miastem, ale też o samym regionie, o otaczającej go przyrodzie, tradycjach, a nawet kulinariach.

Największą popularnością cieszą się trasy rowerowe, które są poprowadzone przez bogate krajobrazowo i kulturowo miejsca. Przez skansen w Olsztynku i rezerwat bobrów biegnie trasa czerwona. Czarna wiedzie przede wszystkim przez las, pozwalając podziwiać walory krajobrazowe. Trasa żółta prowadzi przez lasy i łąki - na niej można odwiedzić także jezioro oraz miejsca pochówku żołnierzy ${ }^{17}$.

Popularną tutejszą rozrywką stały się spływy kajakowe. Dzięki świetnym naturalnym walorom krajobrazowym, bowiem rzeki i jeziora są otoczone dziką przyrodą, miejsce to idealnie

\footnotetext{
16 https://olsztynek.pl/turystyka/atrakcje-turystyczne/ (dostęp: 20.11.2020).

17 https://olsztynek.pl/turystyka/szlaki-turystyczne/ (dostęp: 14.12.2020).
} 
nadaje się do rekreacyjnego spędzania czasu. Spływy nie są wymagające, a ich głównym celem jest wzbudzenie emocji dzięki formie meandrujących rzek, otwierających się na obszarach jezior i zamykających na powrót w wąskich rzecznych korytarzach (il. 7, 8).
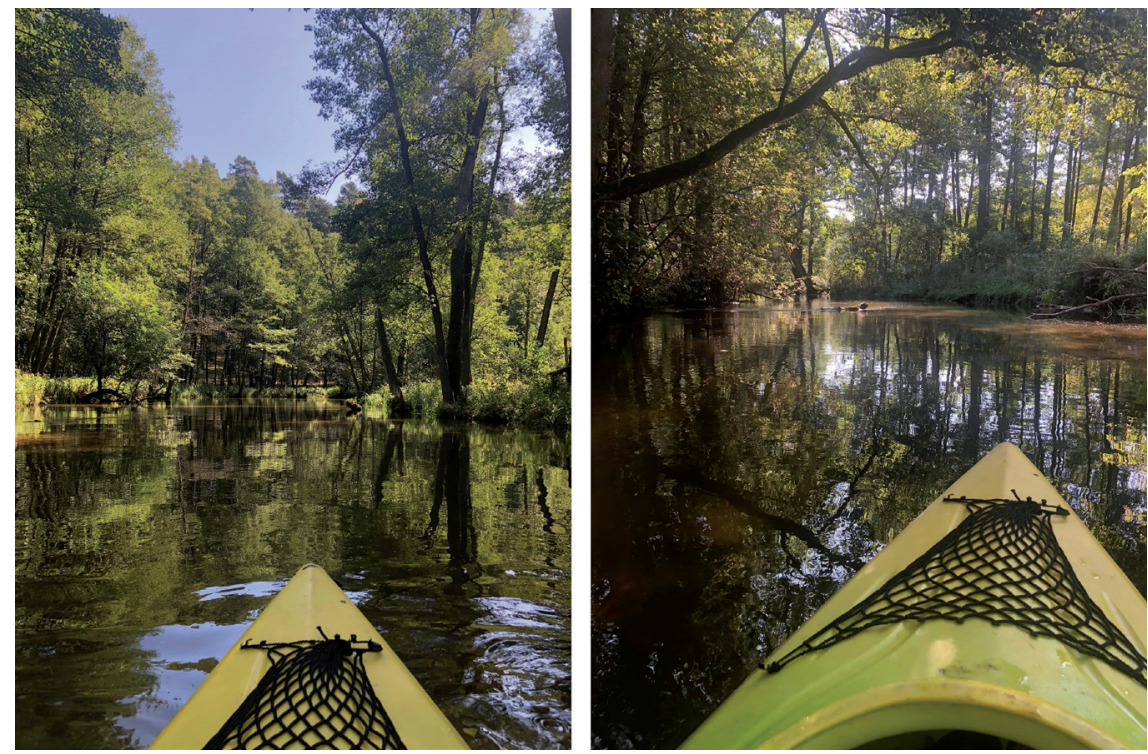

II. 7-8. Spływ kajakowy w Swaderkach. Fot. P. Sobol
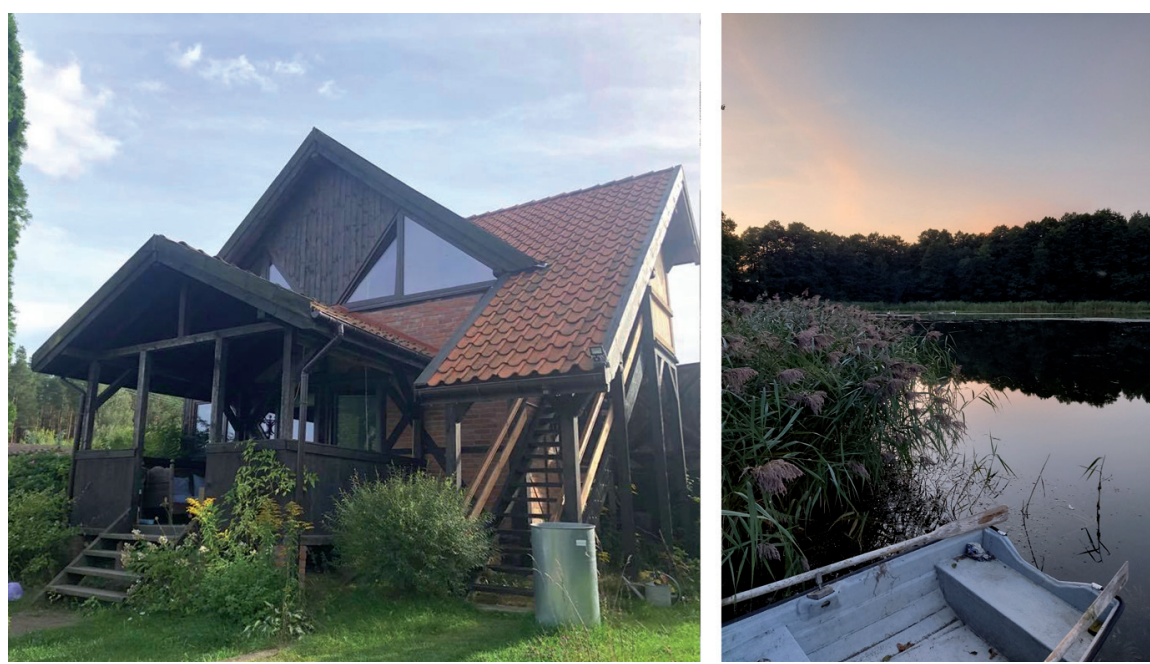

II. 9-10. Archetyp zabudowy - pensjonat „Natura” zestawiony z widokiem na Jezioro Czarne. Fot. autor / P. Sobol 


\section{ANALIZY ZASOBÓW SPOŁECZNO-GOSPODARCZYCH WSI ŚWIERKOCIN}

\subsection{ANALIZA FUNKCJONALNA ISTNIEJĄCEJ TKANKI ZABUDOWY}

W Studium uwarunkowań i kierunków zagospodarowania przestrzennego gminy Olsztynek zawarta jest informacja o ograniczonym rozwoju wsi zgrupowanych na tym obszarze. Głównym uwarunkowaniem Świerkocina są zasoby naturalne związane z różnorodnością przyrodniczą. Mimo nadanego w dokumencie określenia „wsi turystycznej”, miejscowość cechuje się stosunkowo dużą ilością działek siedliskowych w obrębie ulicowego centrum ${ }^{18}$. Sporą część powierzchni, poza obszarami leśnymi i jeziorami, stanowią tereny rolnicze nadające się do upraw rolnych. Są to jednak niewielkich rozmiarów gospodarstwa. Rolnictwo w gminie opiera się przede wszystkim na uprawie ziemi. Niewielka część produkcji rolniczej jest związana z chowem i hodowlą zwierząt. Zajmują się nią zwłaszcza niewielkie gospodarstwa rodzinne. Przykładem przedsiębiorczości rodzinnej są omawiane w tekście gospodarstwa agroturystyczne, tworzące sektor w 100\% składający się z firm rodzinnych (Dorocki, Szymańska, Zdon-Korzeniowska, 2012: 45-60). Miejscowość jest odizolowana, a teren jest w znacznej części niezabudowany, co wpływa na poczucie kameralności. W granicach wsi znajdują się jeziora: Czarne, Oczko, Niskie i Wysokie. Mimo zapisu w studium uwarunkowań o wymaganiu dogęszczania istniejącej tkanki w obszarze zwartej zabudowy wsi, także we wschodniej części powstały punktowo budynki ${ }^{19}$. Znajdują się tam między innymi obiekty turystyczne na wynajem. Obecnie są to domy wakacyjne: Rudle (Świerkocin 85), Certówka (Świerkocin 60) oraz Stodoła Nomada (Świerkocin 69). W południowo-zachodniej części wsi znajduje się obecnie zamknięty ośrodek turystyczny nad jeziorem. Centrum wsi posiada uzbrojenie terenu. Spora część zabudowy oraz puste działki siedliskowe posiadają dostęp do cieków wodnych. Zabudowane centrum wsi otoczone jest ze wszystkich stron gęstymi, naturalnymi, objętymi ochroną lasami (il. 11-12).

\footnotetext{
18 https://polska.e-mapa.net/ (dostęp: 03.04.2021).

19 https://planowanie.olsztynek.pl/ (dostęp: 03.04.2021).
} 


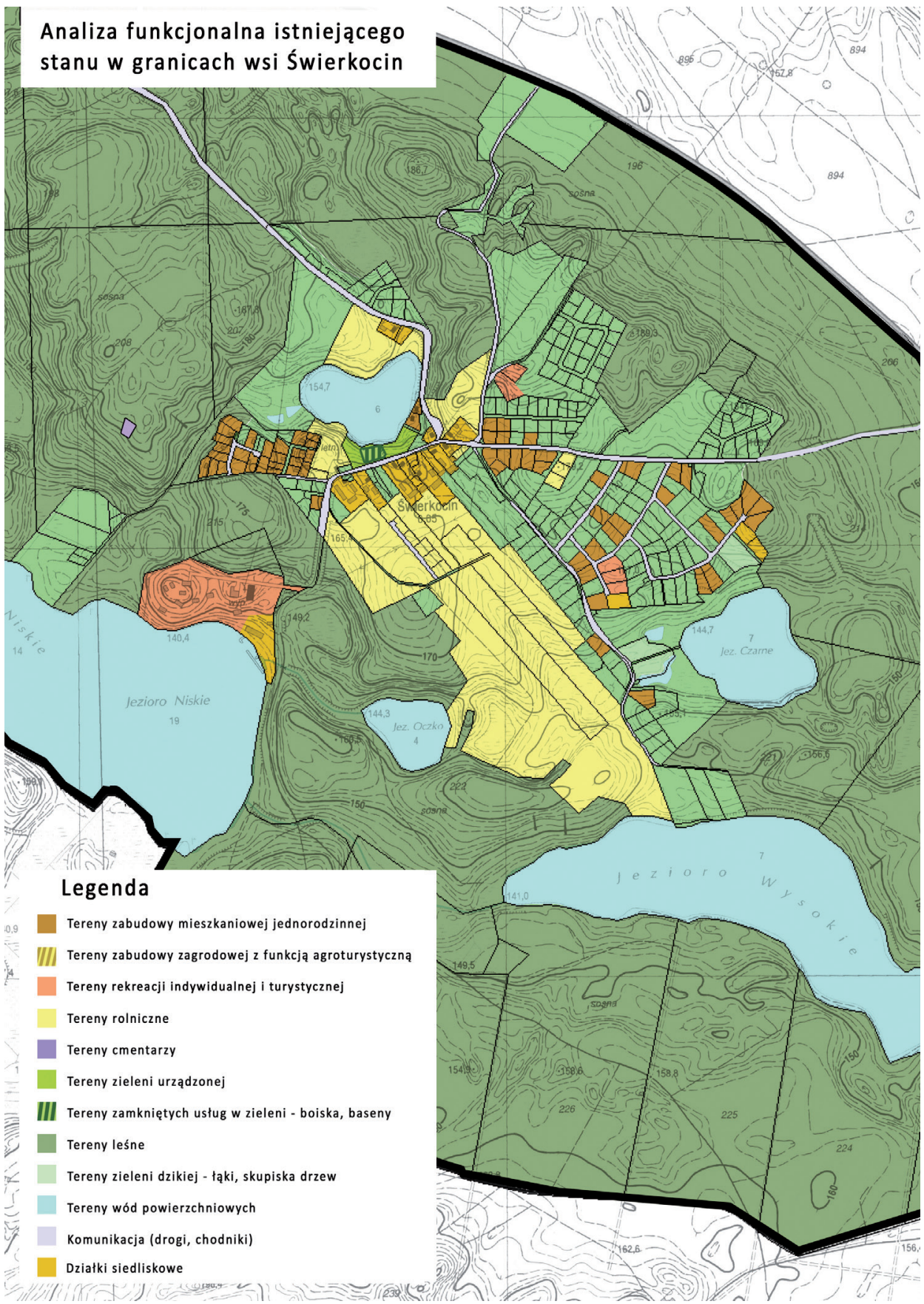

II. 11. Analiza funkcjonalna Świerkocina. Oprac. własne przy współpracy z N. Solewską 


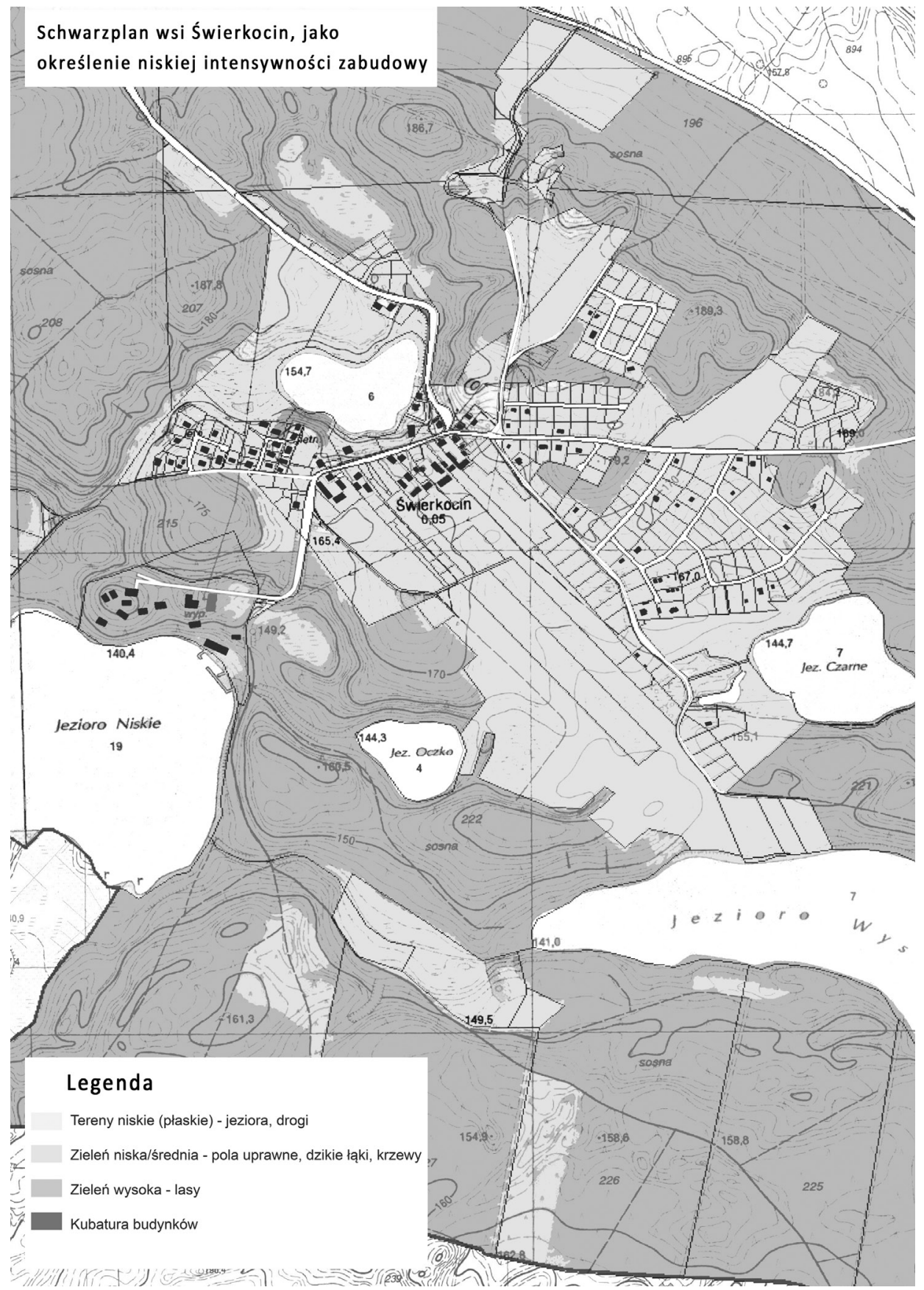

II. 12. Schwarzplan Świerkocina. Oprac. własne przy współpracy z P. Sobolem 


\subsection{ANALIZA ZAPISÓW PLANISTYCZNYCH GMINY OLSZTYNEK W GRANICACH WSI ŚWIERKOCIN}

Wieś nie posiada opracowanego miejscowego planu zagospodarowania terenu dla całości obszaru. Szczegółowe opracowania dotyczą przede wszystkim możliwości sytuowania budynków rekreacji indywidualnej, turystycznej oraz zaznaczają także możliwość zaistnienia zabudowy zagrodowej o funkcji agroturystycznej. W Studium uwarunkowań i kierunków zagospodarowania przestrzennego gminy Olsztynek z 2020 roku zawarta jest informacja o ochronie terenu gminy przed możliwością lokalizacji obiektów związanych z wielkoskalową produkcją rolniczą, która mogłaby negatywnie wpłynąć na funkcjonowanie wielu kameralnych przestrzeni, w tym omawianej wsi. Stąd w ograniczony sposób zostały wyznaczone miejsca na lokalizacje zabudowy związanej z produkcją rolniczą oraz agroturystyką. W tym ostatnim przypadku mają charakteryzować się niewielkimi rozmiarami i rodzinną atmosferą. Za sprzyjające niewłaściwym działaniom uznane są niektóre parcele przeznaczone do lokalizacji zabudowy rekreacji indywidualnej i turystycznej, której dotyczą szczegółowe uwagi. Dogęszczenie zabudowy turystycznej w zachodniej części wsi wykształtowałoby mniejsze subcentra i zdegradowałoby naturalną spójność. Zagrożeniem też stałaby się wyraźna granica między częścią turystyczną zabudowy a częścią wiejską. Funkcje te na obszarach wiejskich (i agroturystycznych) powinny się przenikać w myśl dogęszczania zabudowy oraz aktywizacji społeczności wiejskiej, a nie wykluczać. Obecnie działają tam na stałe trzy obiekty domów wakacyjnych, jednak nie wprowadzają one wspomnianego podziału. Problem wyjaśnia zapis ze studium, który określa, iż przestrzenie te nie rozwijają się znacząco oraz nie są wykorzystywane, przez co nie należy przewidywać dużej ilości nowej zabudowy w tym obszarze. W przestrzeni wiejskiej przeznaczone jest kilka działek do lokalizacji zabudowy zagrodowej z możliwością istnienia funkcji agroturystycznej. Według wytycznych konserwatorskich Świerkocin, tak jak sąsiednie miejscowości, jest objęty ochroną ruralistycznej tkanki zabudowy (il. 13)20.

20 https://planowanie.olsztynek.pl/fileadmin/PLANOWANIE/Studium/20200903_suikzp_zalacznik1.pdf (dostęp: 03.06.2021). 


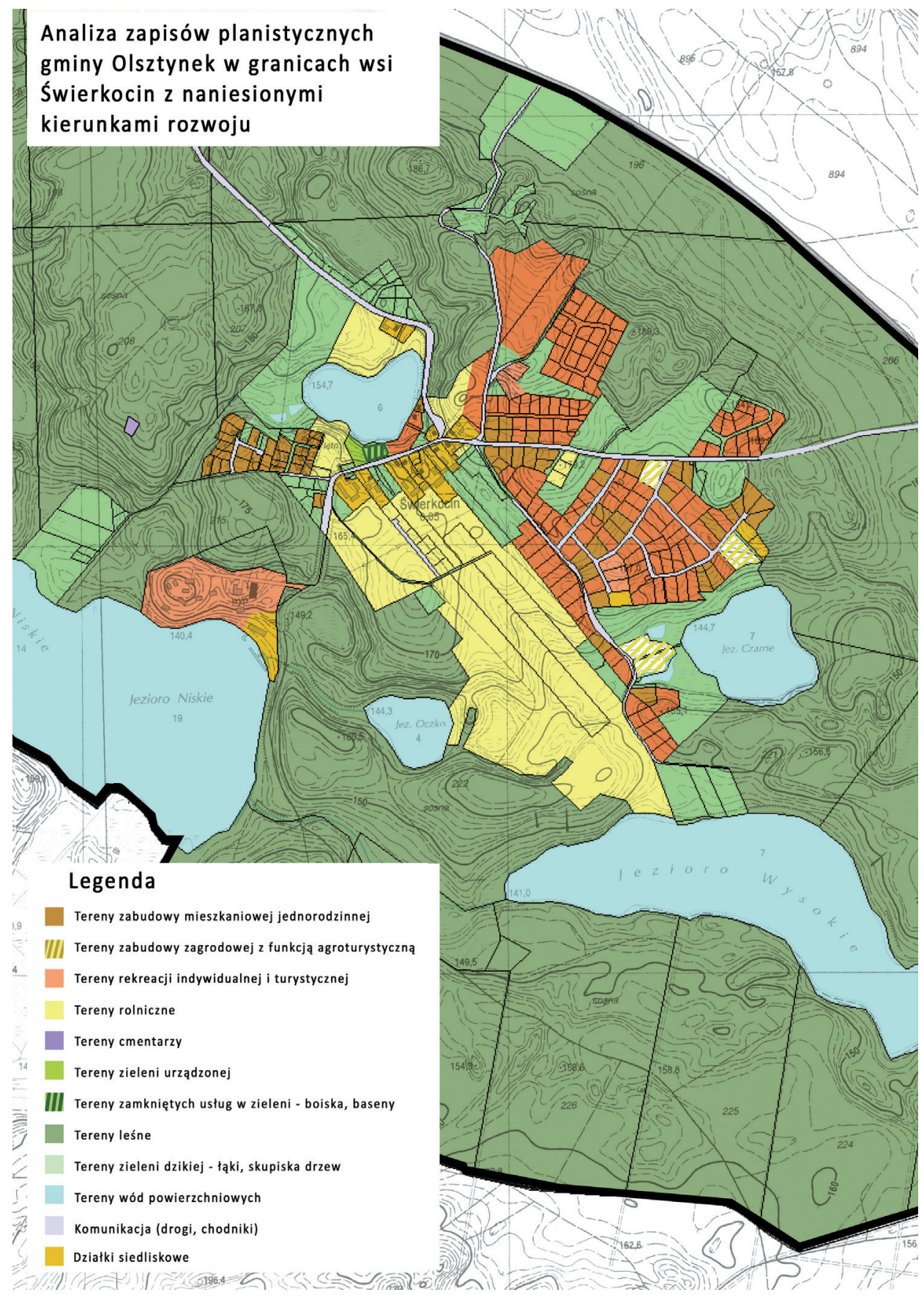

II. 13. Analiza zapisów planistycznych Świerkocina. Oprac. własne przy współpracy z N. Solewską 


\subsection{ANALIZA MOŻLIWYCH PRZEKSZTAŁCEŃ DZIAŁEK SIEDLISKOWYCH W GOSPODARSTWA AGROTURYSTYCZNE}

Na obszarze wsi Świerkocin znajdują się działki siedliskowe, sugerujące status rolnika właściciela, a tym samym osoby mogącej prowadzić gospodarstwo agroturystyczne. Z racji odchodzenia od dominującej roli charakteru rolniczego tereny można przystosować do czerpania zysków z form pozarolniczych. Potencjalne gospodarstwa agroturystyczne mają równy potencjał rekreacyjny, jednak różnią się lokalizacją - część jest ulokowana w obrębie stawów, a inne są zbliżone do tkanki gęstych lasów i borów ${ }^{21}$. Aby dostarczyć dobry produkt agroturystyczny, rozmiary gospodarstw nie muszą być duże. Zapewnienie gościom kontaktu ze zwierzętami lub możliwości udziału w kameralnym agrobiznesie może uwiarygodnić pobyt w ramach rolniczej turystyki. Przekształcenie działek siedliskowych uwydatni wiejski, a także turystyczny charakter miejscowości w nieinwazyjny sposób. Ruralistyczna przestrzeń centrum zostanie zachowana oraz wzbogacona o funkcje wspomagające działalność gospodarstwa. Ze względu na niski wskaźnik gęstości zaludnienia oraz zrównoważony rozwój kameralna przestrzeń nie będzie zakłócana przez hałas czy wzmożony ruch samochodowy. Przestrzeń zlokalizowana przy drodze dojazdowej posiada uzbrojenie terenu, jednak działki oddalone od centrum mają jedynie dostęp do przyłączy wodociągowych i elektrycznych. Obecność dodatkowych atrakcji w okolicy może zachęcić do pobytu na tym obszarze, gdyż może on służyć jako baza wypoczynkowa (Drzewiecki, 2002) (il. 14).

21 https://polska.e-mapa.net/ (dostęp: 03.04.2021). 


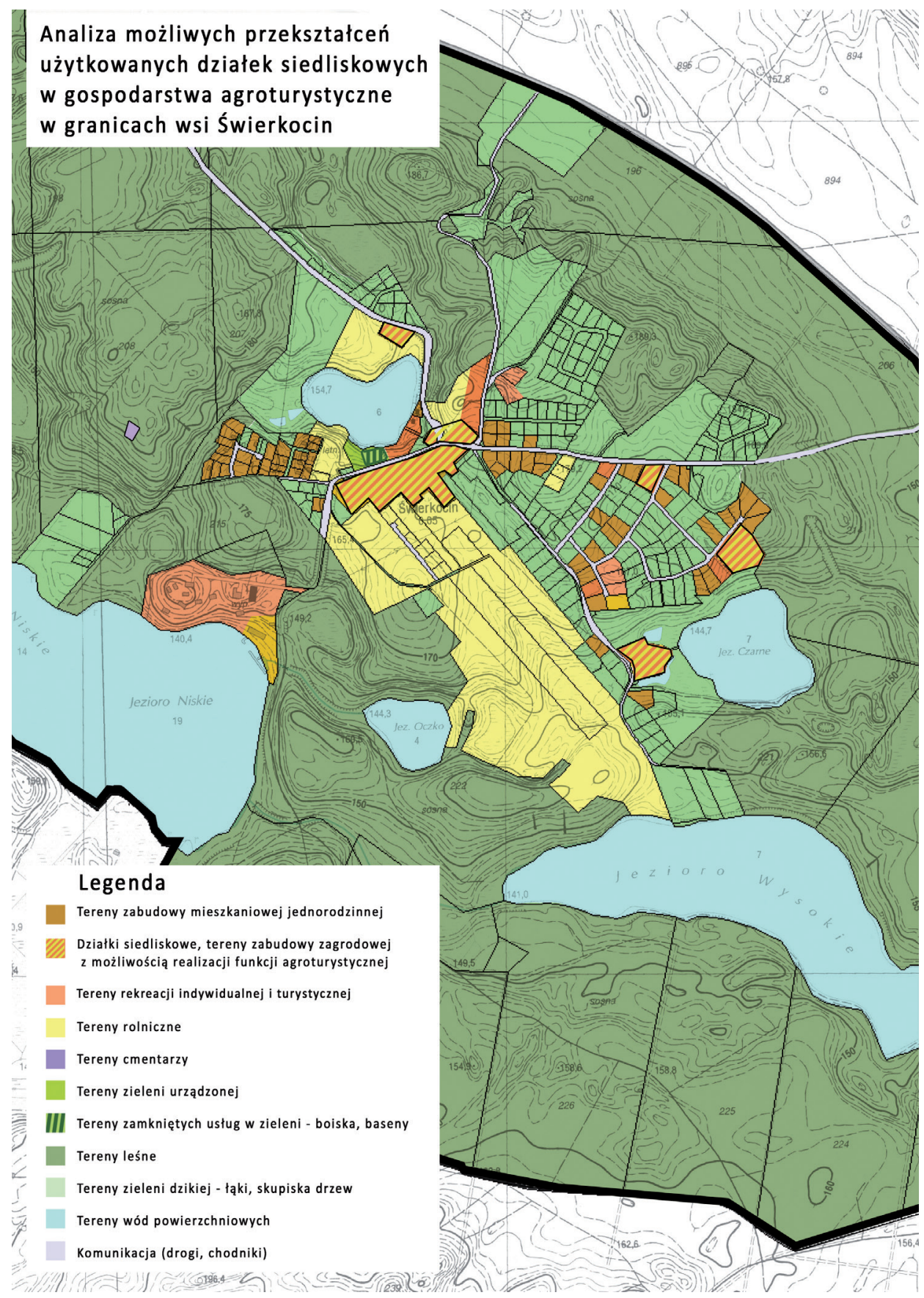

II. 14. Analiza możliwych przekształceń działek rolniczych. Oprac. własne przy współpracy z N. Solewską 


\subsection{ANALIZA PROCESU ROZWOJU}

W Świerkocinie w dokumentach planistycznych występuje ograniczenie wielkoskalowej produkcji rolnej. Osoby posiadające działki siedliskowe, rekreacyjne lub osoby posiadające status rolnika są kontrolowane w zakresie przedsięwzięć rolniczych. W przestrzeni Świerkocina nie pojawia się też duża ilość nowej zabudowy. Dzięki rygorystycznym zapisom w miejscowych planach zagospodarowania przestrzennego struktura wsi pozostaje spójna. Gmina posiada ofertę inwestycyjną z działkami o przeznaczeniu turystycznym lub rekreacyjnym w przestrzeni Świerkocina (dane z 30 maja 2021 roku). Obecna oferta inwestycyjna jest poszerzana, często udostępniając obszary pod zabudowę rolniczą w dzierżawę. Poskutkowało to realizacją kilku lokalnych inwestycji związanych z budową obiektów turystycznych, charakteryzujących się stylem inspirowanym lokalnym archetypem architektury ${ }^{22}$. W ramach dodatkowej działalności pojawiają się tutaj najczęściej wypożyczalnie sprzętu do łowienia ryb lub kajakowania. Miejscowy plan zagospodarowania przestrzennego ustala na 30\% opłatę z tytułu wzrostu wartości nieruchomości o charakterze turystycznym. Obecny stan inwestycji oraz istniejącej zabudowy zapewnia rozrost w obrębie liniowego centrum. Problemem stają się atrakcyjniejsze widokowo działki z zabudową turystyczną poza centrum, które przerywają i zakłócają istniejącą ciągłość struktury wsi. Stanowią one zagrożenie dla ładu przestrzennego. Gospodarstwa agroturystyczne mogą stanowić rozwiązanie problemu przez produkt turystyczny obejmujący znaczną część przestrzeni wiejskiej oraz integrację tej przestrzeni. Ograniczona rozbudowa miejscowości sprzyja rozwojowi kameralnych form turystycznych, podtrzymujących rolniczy charakter i kultywujących wiejską specyfikę kulturową. Dzięki otwartym, naturalnym przestrzeniom, obecne oraz potencjalne obiekty turystyczne zapewniają możliwość interakcji turystów z tkanką wiejską w nieinwazyjny sposób. Podjęte działania wpisują się w myśl wielofunkcyjnego rozwoju wsi, który stymuluje przedsiębiorczość lokalną mieszkańców w zakresie zasobów Świerkocina (Balińska, Zawadka, 2013: 127-143). Możliwość zlokalizowania tam rodzinnego gospodarstwa zagrodowego przyciąga inwestorów. 8 maja 2021 roku został rozstrzygnięty konkurs na projekt „Siedliska w Świerkocinie”, zorganizowany przez inwestorów Beatę Kozicką i Marka Kozickiego. Obrady jury prowadził Radosław Rybkowski z Uniwersytetu Jagiellońskiego. Zwycięski projekt został opracowany przez Karolinę Włodarczyk i dotyczył koncepcji kompleksu agroturystycznego z cydrownią (il. 15).

22 https://planowanie.olsztynek.pl/ (dostęp: 03.04.2021). 


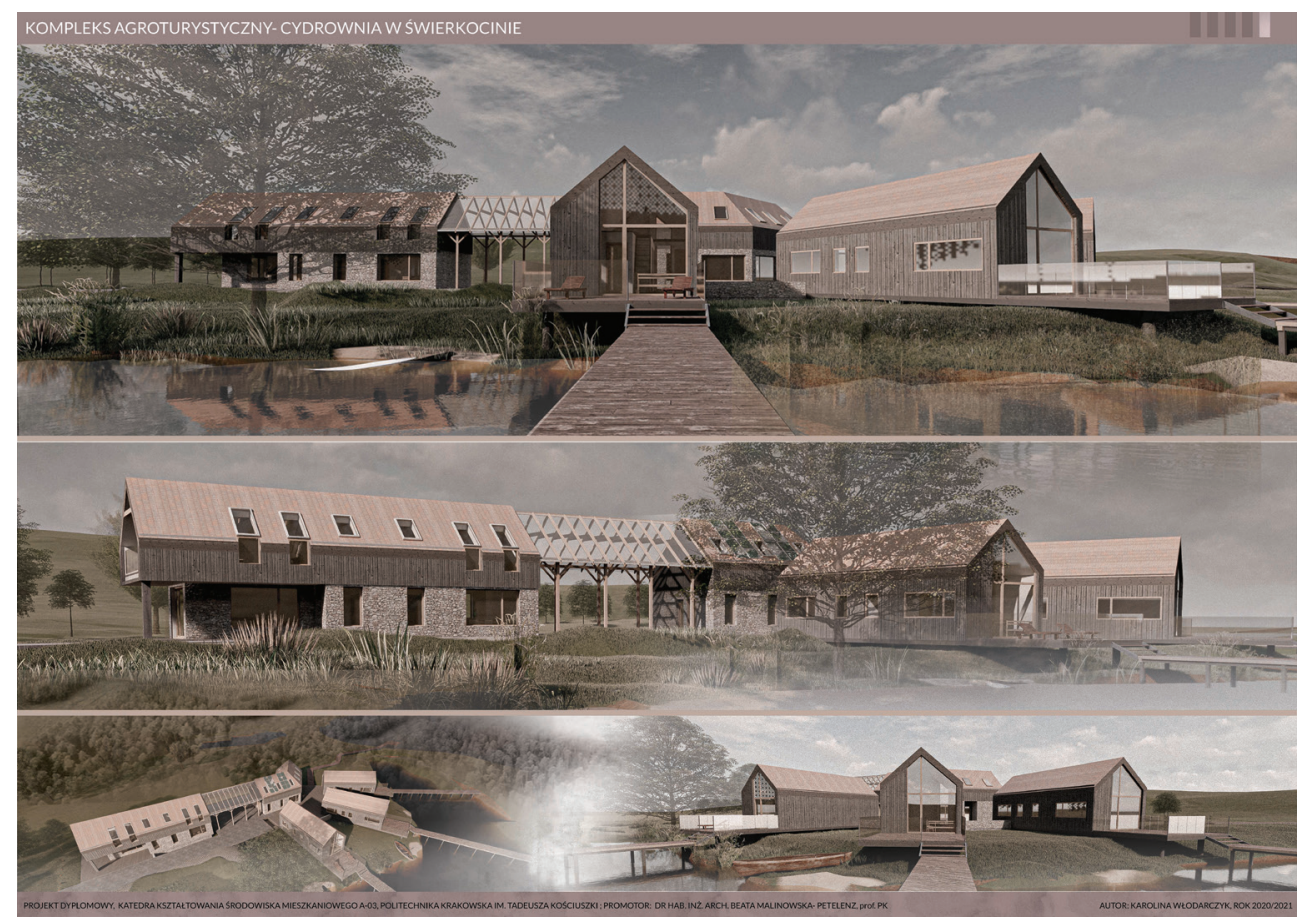

II. 15. Fragment zwycięskiego projektu konkursowego „Siedlisko w Świerkocinie”. Oprac. K. Włodarczyk

\section{WNIOSKI}

Agroturystyka stanowi potencjał rozwoju przestrzennego Warmii i Mazur. Województwo warmińsko-mazurskie jest wypełnione małymi wsiami o różnorodnej strukturze agrarnej. Ich charakter sprzyja powstawaniu struktur agroturystycznych dzięki rozbudowanej tkance naturalnej i kulturowej. Studium przypadku Świerkocina udowadnia, jak istotnym czynnikiem rozwoju przestrzennego jest możliwość lokalizacji gospodarstw agroturystycznych na takich terenach. Rozmiar oraz izolacja wsi w tkance naturalnej zieleni, bliskość jezior, możliwości obserwacji hodowlanych i dzikich zwierząt są ważnymi aspektami dla potencjalnego gospodarstwa agroturystycznego. Świerkocin cechuje się jednym z najniższych wskaźników gęstości zaludnienia w rejonie, może zachęcać indywidualistów poszukujących odosobnienia oraz rodziny oczekujące spokoju. Jednocześnie leśne otoczenie nie stanowi utrudnienia w dojeździe do placówek turystycznych ani korzystania z przewidywanych atrakcji. W dokumentach planistycznych wsi Świerkocin przewidziany jest zrównoważony i ograniczony plan rozwoju, który reguluje dogęszczanie zabudowy i obejmuje ochroną tkankę naturalną oraz kulturową, m.in. chroniony ruralistyczny układ wsi ulicowej. Są to podstawowe czynniki do wiarygodnego 
i efektywnego zaaranżowania wiejskiej turystyki. Nie mniej kluczowe jest poprawne zorganizowanie gospodarstwa rolnego, w którym ulokowane zostałyby funkcje agroturystyczne. Zalecenia władz regionalnych, dotyczące odejścia od bezpośredniej dominacji wielkoskalowej produkcji rolnej, oraz możliwe dofinansowania przedsięwzięć z różnych źródeł zachęcają rolników do poszerzania i zmiany oferty. Poszerzeniem takiej oferty oraz aktywizacją społeczności wiejskiej może być powstanie gospodarstwa agroturystycznego. Aktywizacja wsi wzbogaciłaby rozwój lokalnych form usług w zakresie handlu, przetwórstwa oraz gastronomii. Funkcje tego rodzaju urozmaicałyby ofertę wypoczynkową przy jednoczesnym zachowaniu naturalnej wiejskiej tkanki. Na produkt turystyczny w miejscowości Świerkocin składają się duże naturalne przestrzenie objęte ochroną, flora i fauna niespotykane w innych rejonach kraju, system traktów oraz ścieżek spacerowych, spływy kajakowe czy współgrające z nimi elementy tożsamości kulturowej obszaru, czyli muzea, archetypy architektury czy lokalna kuchnia. Całość nie narzuca się w odbiorze. Odwiedzający ma przeświadczenie, że sam odkrywa ten obszar, mimo rozwiniętej już tkanki turystycznej. Dodatkowym aspektem, sprzyjającym powstawaniu struktur agroturystycznych, jest liczba działek siedliskowych i małych gospodarstw w granicach wsi. Z racji dogodnych warunków, niewielkich rozmiarów, wsparcia władz regionalnych i podatnego rynku mogłyby one poszerzyć zakres swojej działalności.

\section{BIBLIOGRAFIA}

Balińska, A., Zawadka, J. (2013). Znaczenie agroturystyki w rozwoju obszarów wiejskich. Zeszyty Naukowe SGGW. Ekonomika i Organizacja Gospodarki Żywnościowej, 102, 127-143.

Czaplicka-Kozłowska, I. (2009). Agroturystyka w strategiach rozwoju gmin Warmii i Mazur. Roczniki Naukowe Stowarzyszenia Ekonomistów Rolnictwa i Agrobiznesu, 11(3), 56-61.

Darmochwał, T., Rumińsk, M.J. (1996). Warmia i Mazury. Przewodnik. Białystok: Agencja TD. Dębniewska, M., Zaworska, T. (1998). Produkty markowe w strategii rozwoju turystyki wiejskiej w Polsce północno-wschodniej. W: Marketing i produkty markowe w turystyce wiejskiej. Warszawa: Wydawnictwo Naukowe Szkoły Głównej Gospodarstwa Wiejskiego, Katedra Ekonomiki i Organizacji Gospodarstw Rolnych.

Diagnoza wybranych aspektów warunków życia środowisk popegeerowskich w województwie warmińsko-mazurskim. (2015). Olsztyn: Urząd Marszałkowski Województwa Warmińsko-Mazurskiego w Olsztynie, Regionalny Ośrodek Polityki Społecznej, Regionalne Obserwatorium Terytorialne, Obserwatorium Polityki Społecznej.

Dorocki, S., Szymańska, A.I., Zdon-Korzeniowska, M. (2012). Polskie gospodarstwo agroturystyczne jako przedsiębiorstwa rodzinne. Przedsiębiorczość i Zarzqdzanie, 12(8), 45-60.

Dorocki, S., Szymańska, A.I., Zdon-Korzeniowska M. (2013). Przedsiębiorstwa agroturystyczne w gospodarce opartej na wiedzy. Prace Komisji Geografii Przemysłu Polskiego Towarzystwa Geograficznego, 24, 38-58. 
Drzewiecki, M. (2002). Podstawy agroturystyki. Bydgoszcz: Oficyna Wydawnicza Ośrodka Postępu Organizacyjnego.

Dziechciarz, T. (2007). Agroturystyka - nowa forma aktywności ekonomicznej ludności wiejskiej w Polsce. W: W. Kurek, R. Pawlusiński (red.), Studia nad turystykq. Prace ekonomiczne i społeczne. Kraków: Instytut Geografii i Gospodarki Przestrzennej Uniwersytetu Jagiellońskiego.

Gurgul, E. (2005). Agroturystyka jako element rozwoju i promocji regionu. Częstochowa: Sekcja Wydawnictwa Wydziału Zarządzania Politechniki Częstochowskiej.

Jalinik, M. (2009). Uwarunkowania i czynniki rozwoju usług turystycznych na obszarach wiejskich. Problemy Zarzqdzania, 3, 119-137.

Kapusta, F. (2008). Agrobiznes. Warszawa: Wydawnictwo Difin.

Kuźniewski, B. (2007). Olsztynek. Miasto i gmina. Olsztynek: Towarzystwo Przyjaciół Olsztynka. Majewski, J. (2000). Agroturystyka to też biznes. Warszawa: Wydawnictwo Fundacji Wspomagania Wsi.

Marciszewska, B. (2010). Potencjał turystyczny regionu a kreowanie jego wizerunku. Zeszyty Naukowe Uniwersytetu Szczecińskiego. Ekonomiczne Problemy Usług, 52, 13-21.

Marks-Bielska, R., Babuchowska, K. (2013). Uwarunkowania rozwoju agroturystyki w województwie warmińsko-mazurskim według opinii właścicieli gospodarstw rolnych. Folia Pomeranae Universitatis Technologiae Stetinensis. Oeconomica, 70, 141-150.

Sikora, J. (2012). Agroturystyka-przedsiębiorczość na obszarach wiejskich. Warszawa: C.H. Beck. Surdacka, E. (2017). Pojęcie i geneza rozwoju agroturystyki. Autobusy: Technika, Eksploatacja, Systemy Transportowe, 18(6), 1778-1783.

Toeppen, M. (2004). Historia okręgu i miasta Olsztynek. Dąbrówno: Oficyna Wydawnicza Retman.

Wiśniewski, E. (2006). Wprowadzenie do turystyki i rozwój zrównoważony w turystyce. W: M. Skup, M. Małecka-Dobrogowska, K. Kitlas (red.), Akademia Agroturystyki i Rękodzielnictwa. Materiały szkoleniowe (s. 14-18). Białystok: Wydawnictwo D3 Studio.

Wojciechowska, J. (2006). Geneza oraz ewolucja turystyki na obszarach wiejskich w Polsce. Folia Turistica, 17, 99-119.

Wojciechowska, J. (2018). Agroturystyka. Signum turystyki i obszarów wiejskich. Warszawa: Polskie Wydawnictwo Ekonomiczne.

https://agroturystykapolska.pl/artykuly/wakacje-na-wsi-1/moda-na-agroturystyke-4 (dostęp: 20.02.2021).

https://agroturystyka-zakrzewscy.pl/ (dostęp: 27.06.2021).

https://bdl.stat.gov.pl (dostęp: 27.06.2021).

http://encyklopedia.warmia.mazury.pl/index.php/Wojew\%C3\%B3dztwo_warmi\%C5\%84sko-mazurskie (dostęp: 03.04.2021).

https://www.gddkia.gov.pl/pl/ (dostęp: 27.06.2021). 
https://invest.warmia.mazury.pl/pl/dlaczego-warmia-i-mazury/nasze-przewagi.html (dostęp:

28.04.2021).

https://koloniamazurska.pl/ (dostęp: 27.06.2021).

https://natura-group.com.pl (dostęp: 27.06.2021).

https://olsztynek.pl/miasto-i-gmina-olsztynek/przyroda/ (dostęp: 13.12.2020).

https://olsztynek.pl/turystyka/atrakcje-turystyczne/ (dostęp: 20.11.2020).

https://olsztynek.pl/turystyka/szlaki-turystyczne/ (dostęp: 14.12.2020).

https://olsztynek.pl/turystyka/zabytki/ (dostęp: 20.11.2020).

https://planowanie.olsztynek.pl/ System Informacji Przestrzennej (dostęp: 03.04.2021).

https://planowanie.olsztynek.pl/fileadmin/PLANOWANIE/Studium/20200903_suikzp_zalacznik1.pdf (dostęp: 03.04.2021).

https://planowanie.olsztynek.pl/obowiazujace-plany/plany-na-terenie-gminy/ (dostęp: 13.12.2020).

https://polska.e-mapa.net/ (dostęp: 03.04.2021). 
